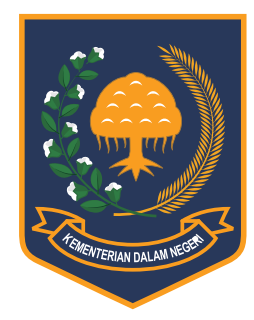

\title{
ACHIEVEMENT, OBSTACles, AND Challenges in the Development of Creative Economy's Best Product in The City OF BANDUng AND BADUng DisTrict
}

\author{
Rosmawaty Sidauruk, Tini Apriani*, Moh Ilham A Hamudy \\ Research and Development Agency, Ministry of Home Affairs of the Republic of Indonesia \\ Jl. Kramat Raya No. 132 Jakarta Pusat
}

Received: 12 March 2019; Accepted: 18 April 2019; Published online: 31 May 2019

DOI: $10.21787 / \mathrm{jbp} .11 .2019 .87-97$

\begin{abstract}
The government issued various regulations to support the development of a creative economy. However, the regulations had not provided a significant impact on the development of the creative economy product in the regions. This study observed the state of the creative economy's Regional Best Products (Produk Unggulan Daerah/PUD), the effort to develop it and the obstacles to its development in the City of Bandung and Badung District. This study used a descriptive method with a qualitative approach. The data was collected using interviews, FGD, and documentation. The study showed that the development of the creative economy's regional Best Products was not optimal This was due to the inability of the existing regulation to provide a significant impact, although the regional government conducted various development efforts in line with the capability of the region.
\end{abstract}

Keywords: Regulations, Regional Products, Creative Economy.

\section{INTRODUCTION}

Currently, the creative economy drives Indonesia's economic growth in three sub-sectors: culinary, fashion, and handicraft (Ginting, Rivani, Saragih, Wuryandani, \& Rasbin, 2018). The growth of the creative economy is getting more important for Indonesia. The Indonesian creative economy sector contributed IDR852 trillion or 7.38 percent of gross domestic product (GDP) in 2015. In 2016 it contributed IDR922,58 trillion to the GDP and absorb $13,47 \%$ of labor. In 2017 , it contributed IDR990 trillion to the GDP and absorb 17.4 percent of the labor. In 2018 it was expected to contribute IDR1,041 trillion to the GDP and absorb 18.2 percent of labor (Nurfadilah, 2018).

Mayangsari \& Setiawan (2017) compares two periods (2002-2006 and 2014-2015) and concludes that the average contribution of the creative economy of the Indonesian economy continues to increase. It is shown on the increase of Economic Value Added, sectoral contribution to Gross Domestic Product, job provision, and the absorption of national labor.
The government issued several policies related to the creative economy, as guidelines to develop and maintain the elements of the creative economy in society (Sugiarto, 2018). Such regulations are Law No. 20 of 2008 on Micro and Small Medium Enterprise (MSME), Law No. 33 of 2009 on Motion Picture, Law No. 3 of 2014 on Industry, Law No. 28 of 2014 on Copyrights and Law No. 7 of 2014 on Trade. Aside from that, a Creative Economy Agency (Badan Ekonomi Kreatif/BEKRAF) was formed, via Presidential Regulation No. 6 of 2015 on the Creative Economy Agency and Presidential Regulation No. 72 of 2015 on the Amendment of the Presidential Regulation No. 6 of 2015 on the Creative Economy Agency.

Presidential Regulation No 72 of 2015 classified the creative economy products into the 16 subsectors: (1) Applications and Games Developer, (2) Architecture, (3) Interior Design, (4) Visual Communication Design, (5) Product Design, (6) Fashion, (7) Animation, Movie \& Video, (8) Photography, (9) Handicraft, (10) Culinary, (11)

\footnotetext{
* Corresponding Author

Phone : +6281392584787

Email : tiniapriani.bppkemendagri@gmail.com
} 
Music, (12) Publications, (13) Advertising, (14) Performance Arts, (15) Sculpture and Painting, and (16) Television \& Radio. The various regulations are intended to build and support the community's creativity with adequate facilities, creating jobs for the community and increase its competitiveness, and encourage Indonesia's economic growth (Badan Ekonomi Kreatif, 2017).

The current and future efforts to develop the creative economy are still facing problems. First, the announcement of the creative economy's 16 sub-sector was not accompanied by a systemic deployments effort, especially in the supporting regulations and infrastructures. It means that the majority of regional governments do not fully realize that the creative economy is the new drive that can add value to the economy, and even trigger regional competitiveness. Second, the creative economy and its economic benefits have not triggered the regional governments to swiftly respond by issuing appropriate arrangements and supports for the development of the creative businesses and products that can add value to the economy and provide benefit to the community. Third, the diverse culture and the variety of the region's resources has encouraged the community to produce creative products. However, the regional governments have not made adequate efforts to elevate their regions' potential, culture, and characteristics, to stimulate the birth of its local entrepreneurship that can contribute to its economic growth and also triggers the regional (or even the national) competitiveness (Ginting et al., 2018).

In that context, this study discussed the development of the creative economy's Region's Best Product (Produk Unggulan Daerah/PUD) in the City of Bandung, West Java and Badung District, Bali. The Presidential Instruction No. 6 of 2009, stated that Creative Economy are economic activities which are based on the individual creativity, skill \& talent, generating individual creation and invention with economic value and benefit for the people (Muhamad, Siregar, Muhammad, \& Fahlevi, 2009). The creative economy is the new economy era after the agricultural economy, industrial economy, and information economy, which intensifies the use of information and creativity by relying on the ideas and knowledge of human resources as the main production factor in its economic activities (Kementerian Pariwisata dan Ekonomi Kreatif RI, 2014).

The creative economy is closely related to the creative industries; however, it has a wider range than creative industries the creative economy is an ecosystem where there are mutual dependence relationships between the creative value chain, the nurturance environment, the market, and the archiving activity. The creative economy is not only related to the creation of economic value (Pahlevi, 2017) but also the creation of added value in the region's cultural-social life and the environment. Therefore, besides improving the competitiveness of the country, the creative economy can also improve the quality of life of the people of Indonesia (Kementerian Pariwisata dan Ekonomi Kreatif RI, 2014).

The PUD referred to in this study is described in the Regulation of the Minister of Home Affairs No 9 of 2014, as a product of both the goods and services produced by cooperatives, small and medium scale business that have the potential to be developed further to take advantage of all the resources owned by the region (whether natural resources, human resources, and local culture), generate income for the community and the government, and expected to be an economic force for the region and its community. A product that has the potential to be competitive, marketable and the drive to enter into the global market (Chuzaimah \& Mabruroh, 2008; Krismawan, 2016). Development in this study is the efforts in developing the PUD through planning, organizing, financing, monitoring, supervision, and evaluation of activities by the local community, the national government, and regional government.

This study assumed that each district has its PUD from its natural and human resources, and expected that the number of PUD would increase with time (Rumengan \& Fatimah, 2015). However, the study found that not all regions have PUD that meets the criteria of a Best Product. Even if the PUD meets the criteria, it has not been optimally developed to generate revenues and improve its community's economy (Yolamalinda, 2014). This is the underlying reason for this study, to understand the development of the creative economy's PUD in Badung District, Bali and the city of Bandung, West Java.

The City of Bandung with its creative economy has 400 shops showcasing the creative industry products, employing approximately 334.224 persons, and contributing 11 percent to the city's economic growth. (Herawati, Rudatin, \& Akbar, 2014). There are some obstacles in the growth of the creative economy in the city of Bandung: lack of facilities to develop the business, difficulty to access capital assistance from the banking sector, lack of government stimulus package in the form of ease of licensing and tax relief to encourage creative industry players to grow into top entrepreneurs, and piracy and copyright infringements of the creative economy products (Simatupang et al., 2008). 
Slightly different from the City of Bandung, Badung District has many PUDs, and some are designated as a PUD with the decision of Badung District Head. From the four PUDs assigned by the decision of Badung District Head, only one is in the creative economy sector, the traditional umbrella handicraft industry (Darna, 2018). To support the development of the creative economy, Badung District has issued various regulations. Unfortunately, business players are not aware of the existence of this development policy. Further hurdles in the PUD development are the limited number of communities formed, limited businesses have appropriate licenses and copyrights, lack of proper education, and limited availability of secondary data (Denpasarkota.go.id, 2018).

Saksono (2012) stated that the creative economy is ideas that are expected to add value to the economy. The creative economy is an alternative solution to economic problems. However, it continues to have some obstacles in the field. Saksono recommended that the national and the regional governments should immediately build commitments, improve regulations and actualize the creative economy, to stimulate economic growth and improve the regional and national competitiveness. Sidauruk (2013) in their study on the role of regional government in the development of the creative economy in West Java found that the problems encountered by regional government among others are the difficulties in distinguishing between creative industry and other industries, causing the budget to be lumped together; complicated licensing investment and copyright protection; capital issues and a lack of resources to support research on the creative economy.

Similar to Sidauruk's study, Mudrajad Kuncoro (a UGM economist) stated that creative industries have 3 fundamental issues: 1) capital, 2) market), and 3) raw materials. The government must address these problems immediately by issuing government policies/ regulations, to support the business players and provide an opportunity to grow, especially for Micro, Small \& Medium Enterprises (MSME) (Nusabali.com, 2017).

Currently, in-depth study related to the development of the creative economy is still unavailable. The previous studies on the creative economy generally were limited to partial analysis, micro, and sectoral. A study by (Fitriana, Noor, \& Hayat, 2014) was conducted on the handicrafts sector in Batu, which showed that the growth of the handicraft sector improves the welfare of the city of Batu. A study conducted by (Ananda \& Susilowati, 2017) in the city of Malang, found that the city has a lot of potentials in the 15 sub-sector of the creative industries, each with their own strength, weakness, opportunities, and threats. It also found some obstacles in the development of the creative industry's MSME, which are human resources, institutional and marketing problems.

Utama \& Darwanto (2013), stated that the creative economy's MSME in the City of Semarang is not the main economic pillar in the City of Semarang. The large industries still dominate the economy of the city. The creative economy entrepreneurs in Semarang are also had problems in the capital, raw materials and production factors, employment, transactions costs, marketing, and copyright.

Unlike the studies above, this study aimed to observe the development of the creative economy's PUD in Badung District, Bali and the City of Bandung, West Java. To achieve that objective, this study focused on the discussion of the state of development of the PUD, the efforts to develop the PUD, and obstacles on the development of PUD in the city of Bandung and Badung district.

\section{MethoD}

This study used a descriptive method with a qualitative approach to get the overall picture of the development of the creative economy's PUD. Primary data collected through Focus Group Discussions (FGD) and in-depth interviews of the sources in the area of study (the regional head/ secretary/assistant in the field of the economy, the Regional House of Representatives (DPRD) of the District/City, the Regional BEKRAF, Regional Development Planning Agency, The District/City Industry Unit, the PTSP (investment and licensing unit), businessman/business players, journalists and NGOs and academics). Secondary data obtained through analysis of literature, books, scientific reports, study reports, and the national and regional government regulations on PUD and creative economy from the Work Unit of The Creative Economy Organizer. The data was then presented in a way to easily understand it. It then verified, and if needed, further data would be searched to obtain stronger data. It was then further analyzed by taking into account the various regulations or documents, other theories and other studies related to the development of PUD in the creative economy.

The study was conducted from February to April 2018, with the location of the study in Badung District and the City of Bandung. The locations of the study were selected because they were the locations of a pilot project in the development of PUD in the creative economy from the aspects of employment and contribution of the Region's GDP. 


\section{RESULTS AND DISCUSSION}

\section{A. The State of Development of the PUD in the City of Bandung}

The city of Bandung is one of the cities that do not have natural resources and energy but have a big potential for human resources (Salim, 2014). This city is dominated by the service sector such as tourism and creative industries. Trade centers especially culinary tourism and factory outlets are the leading sectors. The city of Bandung has private and state-owned universities with good reputations, and also known as the center of education. It has a special appeal for the newcomers (Hafiz, 2019).

The city of Bandung has 6 basic productions being developed as their PUDs: textiles and its products, socks, electronics, crochet, telematics, and automotive components. Currently, there are 270 PUDs and 30 industry centers developing independently. The 270 creative economy's PUDs comprised of 77 food and beverage products, 33 handicraft products, 108 fashion products, 3 service and creative, 38 metal and spare part products, 3 building products, 1 trade, and 7 agricultural products (Dewi, 2018). The creative economy development in the city of Bandung is implemented based on the Presidential Instruction no 6 of 2009 on the development of a creative economy and RPJMD Mission (IV), with the objective of developing a creative economy to support the creation of Bandung as a creative city. As such, in 2013 a coordination team for the development of the creative economy of the city of Bandung was formed, comprised of the city government, academics, executives, and community. The team has been through three times changes so far.

The City of Bandung provides the support for the development of the creative economy by making an institutional change, changing the task, function and the authority carried out by the Economic Unit (Prodi MPWK - SAPPK Institut Teknologi Bandung \& PUSBINDIKLATREN BAPPENAS, 2017). The institutional changes were introduced in 2017 where one creative economy unit is in charge of the function and authority for the creative economy development. The unit has 3 section heads: creative economy, creative product development, and creative ecosystem development. This institutional support opens up more opportunities for the development of the creative economy as one of the pillars of economic growth in the city of Bandung.

The growth of the creative economy is supported by various communities existing long before the creative economy is promoted by the government. Their presence was not even known by the government back then (Gaunt, 2015). When the government started to be aware of the presence of these communities, the Bappeda facilitates the meeting between the government and the creative community. The meeting resulted in a mutual understanding and lead to more studies on the creative economy, which was discontinued due to the absence of the central government regulation (Direktorat Pengembangan Kawasan Khusus dan Tertinggal Deputi Bidang Otonomi Daerah dan Pengembangan Regional Bappenas, 2008).

Various activities were conducted to further develop the creative economy's sub-sector, such as: conducting a design seminar and facilitating the 2015 Conference; supporting the submission of "City network of Bandung", where Bandung is designated as one of the UNESCO 2015 creative city networks in design; facilitating the formation of Indonesia Creative City network of 2015; and facilitating the Indonesia Festival in 2016. The support for PUD development in the creative economy is also shown through various studies, among others the study on creative city indicator 2015; the study on activation indicator in creative economy sub-sector 2016; and the study of creative economy entrepreneurs in the city of Bandung 2016 (Prayudi, Probosari, \& Ardhanariswari, 2017). As a form of support for the creativity of the Bandung residence, the Bandung Creative Hub (BCH) was established in 2017. $\mathrm{BCH}$ is intended to be a center of creativity, where the community is free to bring their idea and express their creativity. It is expected that the accumulation of creative industries will stimulate a substantial growth of the creative economy for the city of Bandung. This creative center is equipped with various facilities such as classrooms, library, cafe, design shop, gallery, cinemas, and workshop or studio, with a variety of equipment for various sub-sectors such as photography, animation, games, design, music, fashion, and others. BHC management is under the management of the Technical Implementation Unit of the Culture and Tourism Office of the City of Bandung (Mayangsari \& Setiawan, 2017).

When the regulation of the central government on the creative economy and PUD was enacted, it provides an opportunity for City Government of Bandung to insert the elements of the creative economy and PUD to the regional development planning documents (Herawati et al., 2014). With that, the PUD in the creative economy has a certainty to be developed, through activities by the regional government bodies or via economic activities carried out by the private sector and individuals. The creative economy PUD development plan is included in the 2019 development plan, and a 
development road map was made on four areas: tourism and fashion, the business incubator, technology businesses using the latest technology, and the creative economy (Hafiz, 2019).

There are still some obstacles identified in the development of the creative economy PUD. Thirty creative economy centers that currently growing independently need assistance to continue to develop further. The obstacles for the majority of them are related to the infrastructure and capital (Aghnia, Mutiara, Arifah, \& Rubianto, 2016). The number of MSME began to decrease. There is also a need for assistance to increase product quality and sales. One of the facilities given by the government and directly related to the product marketability is the halal certificate: 300 certificates in 2017, and 150 certificates in 2018. Other facilities are trademarks and promotion through various government programs such as little Bandung walk, Bandung store, Bandung mobile, Bandung monologue, and Facebook for Bandung. Various training to improve the quality and also assistance from the experts are also held.

\section{B. The State of Development of the PUD in the Badung District}

The PUD development policy is stipulated in the Decision of Badung District Head No. $7574 / 01 / \mathrm{HK} / 2017$ on the Establishment of the PUD Development team. The formation of the team is a follow up from the Regulation of the Minister of Home Affairs No. 9 of 2014. The team duty and responsibility are to compile data and to develop the PUD of Badung district, organize and determine the products or services that meet the criteria of a PUD and is responsible for the implementation and reporting of the results of the of their task in accordance with the terms in the regulation.

From the three PUD development models, Badung district uses the One Village One Product (OVOP) approach. The OVOP approach is to develop one world class product unique to a region by utilizing its local resources. OVOP Program aims to: 1. Develop PUDs that has a local and international market (exports) potentials; 2). Develop and improve the quality and the value-added of the products to compete with other overseas products; $3)$. Increase the income of the rural communities to reduce urbanization (Pratiwi, Pascarani, \& Winaya, 2016).

The OVOP program can be developed anywhere with certain criteria: 1 . It is a PUD or a core competence and was conducted or developed in that area for generations; 2 ). It is a unique product for the region; 3 ). It is based on the local natural resources;
4). It has good market opportunities for both domestic and international markets (Mahagangga, Anom, Suryasih, Suryawan, \& Mertha, 2015).

Based on the Decree of Badung District Head No. $2173 / 01 / \mathrm{HK} / 2015$ on the Designation of Badung District's PUD, there are 3 (three) products / commodities designated as PUD: 1). Asparagus; 2). Saltwater Fishery; and 3). Mertha Buana Coffee. The Decree of Badung District Head No. 6194/01/ HK/2017 on Designation of Badung District PUD designated the umbrella handicraft as PUD.

Badung District is superior in 71 tourism sectors. There are also lots of potential in other sectors that can be developed optimally for PUD (Jarrakpos.com, 2018). First, on the primary sector, some agricultural commodities, plantations, fisheries, and farms have the potential to be developed as PUD such as the cultivation of cacao and coconut, Bali cow and landrace pig farm, and catfish cultivation. Second, on the secondary sector, several prospective sectors to be developed into PUD are cacao processing, catfish processing, beef processing, pork processing, sculpture and furniture industry, herbal medicine and beauty products, spa products and equipment, aquascape driftwood, woven cloth handicraft industry (Baliexpress. jawapos.com, 2018).

The Assistant for Economy stated that there are 3 sub-sectors specified as PUD: handicraft (woven cloth, wood, traditional umbrella), culinary (herbal, bread, mangroves, drinks), and arts (painting, sculpture). Based on the information from the PTSP, from the 16 sub-sectors identified by Bekraf Indonesia, there are 3 sub-sectors with the big contribution in the growth of the creative economy for Badung District (culinary, fashion and handicrafts) having quite a good quality but still need to be developed more to improve their competitiveness.

A competitive PUD in both local and global market is expected to increase the community's income and also increase the regional competitiveness. The development of the creative economy's PUD provide jobs for the labor force from the surrounding community and reduced the unemployment level (Sravishta, 2014).

The PUD in Badung district has a good potential to be developed further, as noted by the representatives from the Regional Becraft. Badung District has creative human resources. In some areas, raw materials are available to be better exploited. It has good potential to develop the current industry further. In terms of financing, the regional government is willing to facilitate. The market has good potential since Bali is already having consumers from various countries. The 
regional government facilitates the infrastructure and technology needed by the creative economy and also institutionalized it by forming a unit in charge of the creative economy (Isa, 2016).

According to the Regional Berkraf, it has forward and backward leverage (Bekraf, 2016). The forward leverage is that the PUD's will be supported, have innovative marketing, and could promote the creation of another PUD. The backward leverage is that one product, and another product is made in a way that is connected to one another, and as such, they could assist one another, as product package made by several business players. The Industry Office also agreed with the regional Bekraf stating that the PUDs are always receiving supports and innovation to prompt the creation of new products that can be a new PUD. The chance to connect one product to another is quite big since they could be packaged as one tourism package (Maulana, 2014).

A continuing obstacle in the development of the creative economy's PUD is the lack of regulation in the region, on the development of PUD and on the development of a creative economy, mainly in operational matters. Other than that, the lack of licensing, and copyrights (Chandra, 2016).

\section{Efforts to Develop the PUD in the City of Bandung and Badung District}

The city of Bandung, which is known as a city with the creative young generation, is taking a step forward in the development of the creative economy PUD. The regional government of the City of Bandung has incorporated the creative economy's PUD development efforts in the development planning documents to ensure its implementation.

Badung district also has a creative economy's PUD development efforts (Putra \& Kartika, 2013). Badung District is using the OVOP model in the PUD development effort. One of the PUD development efforts for a global marketis by having a Memorandum of Understanding (MoU) between the government and business players in the region. Based on the information from the Assistant of Economic, there is an MoU between the regional government with ICAF (Taiwan) in the development of asparagus plantation and Tani Mertha Medi coffee plantation is facilitated by the Ministry of Cooperatives and SME. There is also an MoU between the regional government and the big business players to develop the small-scale industry. In the MoU, the obligation of the business players is to assist and facilitate the development of small industry players to enable them to compete and grow. At the time of this study done, the MoU is implemented and working well, however, its effectiveness still needs to be increased to include wider participation.

It appears that each of the locations of the study has been conducting development efforts on the creative economy's PUD, in line with the special resources of the region and the ability of the creative economy's business players. In Bandung, the creative economy players have joined various communities in accordance with their fields or joined in the industry centers independently. This provides quite a big influence on the development of the creative economy's PUD. The existence of these clusters will ease cooperation and innovation (Ginting et al., 2018).

Badung District with its OVOP attempts to increase the PUD added value to improve the welfare of the people via cooperatives or SME. This is in accordance with what is mandated in the Regulation of the Ministry of Home Affairs No. 9 of 2014, which specifies that the PUD development planning in region for the medium term can be conducted via these models: 1) incubator, 2), cluster 3) One Village One Product/OVOP and 4) competencies (Triharini, Larasati, \& Susanto, 2014).

Incubator Model is the development process for small businesses and or new product development by a business incubator, who provide business infrastructure, business development, and support of management and technology. Cluster Model provides benefits such as 1) strengthening the local economy; 2) facilitating the reorganization of the industry; 3) increasing the networking between the companies; 4) emphasizing on public resources; 5) increasing productivity and efficiency, and 6) encouraging and facilitating innovation. The OVOP model, with an objective of 1) developing PUDs that have a local and international market potential; 2) developing and improving the quality and the added value of the products to compete with imported products; 3) OVOP activities conducted by the Ministry of Cooperatives and SME must be conducted through co-operatives and SME; 4) improve the community's income (Ratmono, Nedi, \& Yateno, 2016). Core Competence Model, according to the Department of Industry is an integrated collection of skills and technologies as a result of learnings, which would be beneficial for the success of a business in the market competition. In a regional economic perspective, core competence is the ability of a region to attract investment from outside the area, both foreign and domestic investments, and facilitate a value-added economy. A PUD or a featured industry are not seen as a core competence if they are developed traditionally.

It is expected that each region will have a PUD using one of the models suitable for the region's potential and the condition. The region would have 
Table 1.

The Efforts and Obstacles in the Development of PUD Based on the Creative Economy

\begin{tabular}{lll}
\multicolumn{1}{c}{ The City of Bandung } & \multicolumn{1}{c}{ Badung District } \\
\hline The Efforts & \multicolumn{1}{c}{ Inserting the elements of the creative economy and PUD } & The formation of the PUD development team \\
into the regional development planning documents & Using the OVOP approach \\
- Create a creative economic development road map & Provide institutional support \\
- Provide institutional support & - Facilitates the provision of the infrastructure and \\
- Facilitates the meeting between the government and the & technology \\
creative community & Create a Memorandum of Understanding between the \\
- Conducting studies related to the creative economy & government and business players in the region \\
- Facilitates activities related to the creative economy & - Cooperation between the regional government with \\
- Establishment of Bandung Creative Hub & foreign government/consumers
\end{tabular}

been able to elevate the MSME businesses to the national stage and in turn, it can be at the forefront of the economy both nationally and internationally.

\section{Obstacles in Developing the PUD in the City of Bandung and Badung District}

In general the obstacles in the development of creative economy's PUD in the area of the study are: the lack of regulation that is contained in the regional planning documents, lack of creative economic policies and PUD policy that is more specific (Litbang.kemendagri.go.id, 2018), suboptimal guidance and support for the development by the regional government, limited ability of the human resources, limited availability of capital, lack of regulation on raw materials, suboptimal function of cooperatives as the institution in charge for development of PUD, low bargaining power of craftsmen in price determination, administration of patent that takes a long time and expensive, lack of SME development, development PUD not conducted using collaboration or cooperation between the various actors that play a role in the creative industries or industry that requires creativity continuously (Beritabali.com, 2018).
For the City of Bandung, the obstacle is related to the institutional structure of the regional organization, which was changed with the enactment of PP No. 18 of 2016 on Regional Government Units. The Creative Economy section in the city of Bandung has formed one year ago, previously it was conducted by the Economy Unit together with some Regional Governments Work Unit (Satuan Kerja Perangkat Daerah/SKPD). Since 2017, the creative economy development was conducted by the Tourism Office, under the institutional term "creative economy". Synergy and publication to stakeholders need to be improved, via the regional government's website or other information technology means (Bandungcreativecityblog.wordpress.com, 2008).

Other constraints are the lack of facilities to develop the business, the difficulty to access capital assistance from the banks, inability to follow the market trends, lack of stimuli in the form of ease of licensing and tax relief to encourage a creative industry player to be a reliable entrepreneur, and the rampant piracy of the creative economy products (DetikNews.ID, 2019).

Coordination in the development efforts of Badung District still needs to be improved. 
Secondary Data on Creative Economy and PUD is incomplete. The division of tasks and functions in the Regional Government and the synergy/ coordination still need to be improved. From the side of the Human Resources (according to regional Bekraf), the educational levels of business players and local government are still not favorable. The skills of business players and local government (as stated by the source from the Education Department of Industry) are still not adequate.

This is also agreed to by the businessmen. On Policy, the Regional Bekraf and the Industrial Office stated that the regional regulation was well implemented, but more specific regulations on the development of the creative economy need to be issued and support from stakeholders need to be improved. Entrepreneurs have participated in various efforts to empower the small industry through cooperation with the government. The participation from the government, entrepreneurs, and then the creative economy players are needed to improve the competitiveness of the PUD. This participation is focused on a development policy that is based on the regional specialty, using the potential of human resources, institutions, and local physical resources. Currently, even when a PUD is attractive to the national and international markets, there have been no regional regulations on its development or to provide protection to the producer, including those on the creative economy sector (Purwanta, 2009). Those business players are still very vulnerable to various problems such as capital, production and marketing, and needs support from the regional government in the form of regulation that can ensure the survival of the business (Hamdan, 2016).

It is undeniable that the creative economy still has many obstacles, especially in human resources, supporting resources, institution, financing, infrastructure and technology, and marketing. But so far, as noted by an expert in the location of the study, the current regulation do not provide significant impacts for the development of the creative economy, especially development of the creative economy's PUD (Efendi D, 2014).

\section{Conclusion}

The development of the creative economy's PUD is one of the efforts to improve the national economy and also improve regional competitiveness. However, some regions are having difficulties to identify their PUD that has the potential to improve their economy, and in determining the development strategy for their PUD. Although the government has issued regulations to the development the creative economy's PUD, such regulations do not have a significant impact to improve the welfare of the community, provide employment, and increase the region's income. Therefore, a revamp of infrastructure and supporting factors for the growth of the creative economy must be conducted. Strategic steps are needed in the form of the supervision, formulation of regulation/policies that more implementable, budget allocation in the State Budget and the regional budget, strengthening the capacity of the business and the need for partnership, monitoring and evaluation (including the development of the system and its database) to support the creation of a creative economy environment.

\section{ACKNOWLEDGMENT}

The author would like to thank the City of Bandung and Badung District Government and all their officers for their cooperation in this study. The author would also like to thank all the creative economy players in the location of the study and on all stakeholders for their valuable inputs in this study.

\section{REFERENCES}

Aghnia, H., Mutiara, G., Arifah, N., \& Rubianto, L. (2016). Identifikasi Persoalan Ekonomi Kreatif (Studi Kasus: Kota Bandung). Retrieved from https://www.academia.edu/25608276/IDENTIFIKASI_PERSOALAN_EKONOMI_KREATIF STUDI_KASUS_KOTA_BANDUNG

Ananda, A. D., \& Susilowati, D. (2017). Pengembangan Usaha Mikro Kecil dan Menengah (UMKM) Berbasis Industri Kreatif di Kota Malang. Jurnal Ilmu Ekonomi, 1(1), 120-142. Retrieved from http://ejournal.umm.ac.id/index.php/jie/article/view/6072/0

Badan Ekonomi Kreatif. (2017). Rencana Strategis Badan Ekonomi Kreatif 2015-2019. Retrieved from http://www.bekraf.go.id/downloadable/ pdf_file/171014-rencana-strategis-badanekonomi-kreatif-2015-2019.pdf

Baliexpress.jawapos.com. (2018, February 3). Tiap Desa di Badung Dicanangkan Punya Produk Unggulan (I. P. Suyatra, Ed.). Retrieved from Baliexpress.jawapos.com website: https://baliexpress.jawapos.com/ $\mathrm{read} / 2018 / 02 / 03 / 45882 /$ tiap-desa-di-badung-dicanangkan-punya-produk-unggulan

Bandungcreativecityblog.wordpress.com. (2008, May 19). Paradoks Perkembangan Ekonomi Kreatif di Kota Bandung. Retrieved from Bandungcreativecityblog.wordpress.com website: https://bandungcreativecityblog.wordpress. 
com $/ 2008 / 05 / 19 /$ paradoks-perkembangan-ekonomi-kreatif-di-kota-bandung/

Bekraf. (2016). Sistem Ekonomi Kreatif Nasional; Panduan Penilaian Mandiri Kabupaten/Kota Kreatif 2016. Retrieved from https://www.kotakreatif.id/file/PANDUAN PMK3I.pdf

Beritabali.com. (2018, November 7). Kunci Utama Pengembangan Ekonomi Kreatif Adalah Kolaborasi. Retrieved from Beritabali. com website: https://www.beritabali.com/ $\mathrm{read} / 2018 / 11 / 07 / 201811070010 /$ Kunci-Utama-Pengembangan-Ekonomi-Kreatif-Adalah-Kolaborasi.html

Chandra, A. A. (2016, August 26). Ini Kendala yang Dihadapi Pelaku Industri Kreatif. Retrieved from Finance.detik.com website: https://finance.detik.com/berita-ekonomi-bisnis/d-3284282/ini-kendala-yang-dihadapi-pelaku-industri-kreatif

Chuzaimah, \& Mabruroh. (2008). Identifikasi Produk Unggulan Berbasis Ekonomi Lokal untuk Meningkatkan PAD di Era Otda. Seminar Nasional Aplikasi Sains Dan Teknologi 2008, (2002), 28-36. Retrieved from http://repository.akprind.ac.id/repo/conference-paper/identifikasi-produk-unggulan-berbasis-ekonomi-lokal-untuk-meningkatkan-pad-d-0

Darna, I. M. (2018, February 3). Bangkitkan UKM di Badung, Setiap Desa Punya Satu Unggulan, Dekranasda, Perinnaker dan Perajin Badung Gelar Rapat Koordinasi. Retrieved from Balitribune.co.id website: http://balitribune. co.id/content/bangkitkan-ukm-di-badung-setiap-desa-punya-satu-unggulan-dekranasda-perinnaker-dan-perajin

Denpasarkota.go.id. (2018, June 26). Orange Economy Padukan Kearifan Lokal dan Ekonomi Kreatif. Retrieved from Denpasarkota.go.id website: https://denpasarkota.go.id/baca-berita/13847/Orange-Economy-Padukan-Kearifan-Lokal-dan-Ekonomi-Kreatif

DetikNews.ID. (2019, March 1). Bekraf Venture Peningkatan Akses Permodalan Non Perbankan. Retrieved from DetikNews.ID website: https://detiknews.id/17739/ekonomi-bisnis/ bekraf-venture-peningkatan-akses-permodalan-non-perbankan/

Dewi, E. N. (2018, December 10). Enam Produk Unggulan Kota Bandung Hadir di "Weekend Market" Cirebon. Retrieved from Pikiran-rakyat. com website: https://www.pikiran-rakyat. com/ekonomi / 2018/12/10/enam-produk-unggulan-kota-bandung-hadir-di-weekend-market-cirebon-434195

Direktorat Pengembangan Kawasan Khusus dan Tertinggal Deputi Bidang Otonomi Daerah dan
Pengembangan Regional BAPPENAS. (2008). Pengembangan Ekonomi Daerah Berbasis Kawasan Andalan: Membangun Model Pengelolaan dan Pengembangan Keterkaitan Program. Retrieved from https://www.bappenas. go.id/files/4513/5080/2311/10pengembangan-ekonomi-daerah-berbasis-kawasan-andala n-me m ban g u n - model-pengelolaan-dan-pengembangan-keterkaitan-program_20081123002641_9.pdf

Efendi D, S. (2014, October 24). Ekonomi Kreatif: Permasalahan, Tantangan dan Prospeknya. Retrieved from Umm.ac.id website: http://www. umm.ac.id/en/opini/ekonomi-kreatif-permasalahan-tantangan-dan-prospeknya.html

Fitriana, A. N., Noor, I., \& Hayat, A. (2014). Pengembangan Industri Kreatif di Kota Batu (Studi tentang Industri Kreatif Sektor Kerajinan di Kota Batu). Jurnal Administrasi Publik (JAP), 2(2), 281-286. Retrieved from http://administrasipublik.studentjournal.ub.ac.id/index.php/jap/ article/view/371

Gaunt, F. M. (2015). Analisis Terhadap Para Pekerja Industri Kreatif di Kota Bandung. Universitas Katolik Parahyangan.

Ginting, A. M., Rivani, E., Saragih, J. P., Wuryandani, D., \& Rasbin. (2018). Strategi Pengembangan Ekonomi Kreatif di Indonesia (C. M. Firdausy, Ed.). Jakarta: Yayasan Pustaka Obor Indonesia.

Hafiz, M. N. (2019, January 4). Mari Galakkan Ekonomi Kreatif Kota Bandung. Retrieved from Ayobandung.com website: https://www. ayobandung.com/read/2019/01/04/42806/ mari-galakkan-ekonomi-kreatif-kota-bandung

Hamdan. (2016). Kebijakan dan Strategi Pengembangan Ekonomi Kreatif. Study Excursie Mahasiswa Jurusan Ilmu Ekonomi Dan Studi Pembangunan Universitas Muhammadiyah Malang, 1-19. Malang: Universitas Muhammadiyah Malang.

Herawati, T., Rudatin, C. L., \& Akbar, D. (2014). Potensi Kota Bandung Sebagai Destinasi Incentive Melalui Pengembangan Ekonomi Kreatif. Epigram: Jurnal Penelitian Dan Pengembangan Humaniora, 11(2), 95-102. Retrieved from http://jurnal.pnj.ac.id/index.php/epigram/article/view/672

Isa, M. (2016). Model Penguatan Kelembagaan Industri Kreatif Kuliner Sebagai Upaya Pengembangan Ekonomi Daerah. Seminar Nasional Ekonomi Bisnis 2016, 352-361. Retrieved from http://eprints.umsida.ac.id/133/

Jarrakpos.com. (2018, January 28). PAD Badung Dihambur-Hamburkan, Ekonomi Kreatif Belum Tergarap Maksimal. Retrieved from Jarrakpos.com website: https://jarrakpos. 
com $/ 2018 / 01 / 28 /$ pad-badung-dihambur-hamburkan-ekonomi-kreatif-belum-tergarap-maksimal/

Kementerian Pariwisata dan Ekonomi Kreatif RI. (2014). Ekonomi Kreatif: Kekuatan Baru Indonesia Menuju 2025. Jakarta.

Krismawan, H. (2016). Strategi Pengembangan Kerajinan Batik Tulis Sebagai Produk Unggulan Daerah (PUD) di Kabupaten Bantul (Universitas Muhammadiyah Yogyakarta). Retrieved from http://repository.umy.ac.id/handle/123456789/9021

Litbang.kemendagri.go.id. (2018, February 26). Regulasi mengenai Produk Unggulan Daerah Perlu Diperkuat. Retrieved from Litbang.kemendagri.go.id website: http://litbang.kemendagri. go.id/website/regulasi-mengenai-produk-unggulan-daerah-perlu-diperkuat/

Mahagangga, I. G. A. O., Anom, I. P., Suryasih, I. A., Suryawan, I. B., \& Mertha, I. W. (2015). Kajian Pengembangan Desa Wisata di Kabupaten Badung. Seminar Nasional Sains Dan Teknologi (Senastek). Retrieved from https://www.academia.edu/24826896/KAJIAN_PENGEMBANGAN_DESA_WISATA_DI_KABUPATEN_BADUNG

Maulana, A. (2014). Strategi Pengembangan Wisata Spiritual di Kabupaten Badung, Provinsi Bali. Jurnal Kepariwisataan Indonesia, 9(2), 119-143. Retrieved from https://www.academia.edu/38585339/Strategi_Pengembangan_Wisata_Spiritual_Di_Kabupaten_Badung_ Provinsi_Bali

Mayangsari, R. A., \& Setiawan, F. A. (2017). The Identification and Distribution Patterns of Creative Hubs in Bandung. IJCCI - International Journal of Cultural and Creative Industries, 4(2), 62-77. Retrieved from http://www.ijcci.net/index. php?option $=$ module $\&$ lang $=$ en $\&$ task $=$ pagein fo\&id $=232$ \&index $=7$

Muhamad, R. N., Siregar, S., Muhammad, E., \& Fahlevi. (2009). Identifikasi Potensi Ekonomi Masyarakat Kabupaten Tapin Tahun 2009 (BAPPEDA TAPIN). Retrieved from http:// eprints.unlam.ac.id/id/eprint/50

Nurfadilah, P. S. (2018, September 25). Potensi Besar, Ini 3 Subsektor Utama Ekonomi Kreatif di Indonesia. Retrieved from Kompas.com website: https://ekonomi.kompas.com/ $\mathrm{read} / 2018 / 09 / 25 / 202052726 /$ potensi-besar-ini-3-subsektor-utama-ekonomi-kreatif-di-indonesia

Nusabali.com. (2017, August 22). Industri Kreatif Hadapi Tiga Masalah Mendasar. Retrieved from Nusabali.com website: https://www.nusabali.com/berita/17779/industri-kreatif-hadapi-tiga-masalah-mendasar
Pahlevi, A. S. (2017). Gagasan Tentang Pengembangan Ekonomi Kreatif Nasional (Studi pada Potensi, Peluang dan Tantangan Ekonomi Kreatif di Kota Malang). Seminar Nasional Seni Dan Desain: "Membangun Tradisi Inovasi Melalui Riset Berbasis Praktik Seni Dan Desain" FBS Unesa, 185-188. Malang: FBS Unesa.

Pratiwi, K. R. I., Pascarani, N. N. D., \& Winaya, I. K. (2016). Evaluasi Pelaksanaan Program One Village One Product (OVOP) dalam Pemberdayaan Masyarakat di Desa Pelaga, Kecamatan Petang, Kabupaten Badung. Citizen Charter, 1(1), 1-9. Retrieved from https://ojs.unud.ac.id/index. $\mathrm{php} /$ citizen/article/view/23401

Prayudi, Probosari, N., \& Ardhanariswari, K. A. (2017). Analysis of the Development of Bandung as Creative City. International Journal of Scientific \& Engineering Research, 8(9), 10251030. Retrieved from https://www.ijser.org/ researchpaper/Analysis-of-the-Developmentof-Bandung-as-Creative-City.pdf

Prodi MPWK - SAPPK Institut Teknologi Bandung, \& PUSBINDIKLATREN BAPPENAS. (2017). Kerja Sama Pemerintah dan Badan Usaha (KPBU): Studi Kasus TPPAS Regional Lulut Nambo, Kabupaten Bogor. Bandung.

Purwanta, E. (2009). Peranan pemerintah daerah dalam upaya perlindungan hak kekayaan intelektual terhadap produk unggulan daerah di Kabupaten Klaten (Universitas Gadjah Mada). Retrieved from http://etd.repository.ugm. ac.id/index.php?mod=penelitian_detail\&sub$=$ PenelitianDetail\&act=view\&typ=html\&buku id $=42850$

Putra, P. G. B. N., \& Kartika, I. N. (2013). Analisis Sektor-Sektor Potensial Dalam Menentukan Prioritas Pembangunan di Kabupaten Badung Tahun 2001-2011. E-Jurnal EP Unud, 2(9), 401-405. Retrieved from https://ojs.unud.ac.id/index. php/eep/article/view/6367

Ratmono, Nedi, N. H., \& Yateno. (2016). Pendekatan OVOP Sebagai Program Pengembangan Produk Unggulan Wilayah Kota Provinsi Lampung. Derivatif: Jurnal Manajemen, 10(2), 82-90. https://doi.org/10.24127/JM.V10I2.113

Rumengan, I. F. M., \& Fatimah, F. (2015). Pengembangan Penelitian Produk Unggulan Daerah Sulawesi Utara yang Berdaya Saing Memperkuat Posisi Indonesia Menghadapi MEA. Jurnal LPPM Bidang Sains Dan TeknologI, 2(1), 1-13. Retrieved from https://ejournal.unsrat.ac.id/ index.php/lppmsains/article/view/10675

Saksono, H. (2012). Ekonomi Kreatif: Talenta Baru Pemicu Daya Saing Daerah. Jurnal Bina Praja, 04(02), 93-104. https://doi.org/10.21787/ JBP.04.2012.93-104 
Salim, D. A. (2014, September 1). Bandung Menuju Kota Ekonomi Kreatif. Retrieved from SWA.co.id website: https://swa.co.id/swa/ trends/management/bandung-menuju-kota-ekonomi-kreatif

Sidauruk, R. (2013). Peningkatan Peran Pemerintah Daerah dalam Rangka Pengembangan Ekonomi Kreatif di Provinsi Jawa Barat. Jurnal Bina Praja, 05(03), 141-158. https://doi. org/10.21787/JBP.05.2013.141-158

Simatupang, T. M., Yudoko, G., Handayati, Y., Pascasuseno, A., Permadi, K., \& Listiani, W. (2008). Analisis Kebijakan Pengembangan Industri Kreatif di Kota Bandung. Jurnal Managemen Teknologi, 8(1). Retrieved from http://journal.sbm.itb.ac.id/index.php/mantek/article/ view/92

Sravishta, D. A. W. (2014). Pengaruh Sektor Potensial Terhadap Kesempatan Kerja di Kabupaten Bangli. E-Jurnal EP Unud, 3(4), 145-154. Retrieved from https://ojs.unud.ac.id/index. php/eep/article/view/8168
Sugiarto, E. C. (2018, November 13). Ekonomi Kreatif Masa Depan Indonesia. Retrieved from Setkab.go.id website: https://setkab.go.id/ ekonomi-kreatif-masa-depan-indonesia/

Triharini, M., Larasati, D., \& Susanto, R. (2014). Pendekatan One Village One Product (OVOP) untuk Mengembangkan Potensi Kerajinan Daerah (Studi Kasus: Kerajinan Gerabah di Kecamatan Plered, Kabupaten Purwakarta). ITB Journal of Visual Art and Design, 6(1), 29-42. https://doi.org/10.5614/itbj.vad.2014.6.1.4

Utama, D. D. T., \& Darwanto. (2013). Pengembangan Usaha Mikro Kecil dan Menengah (UMKM) Berbasis Ekonomi Kreatif di Kota Semarang (Universitas Diponegoro). Retrieved from http:// eprints.undip.ac.id/40407/

Yolamalinda. (2014). Analisis Potensi Ekonomi Daerah dalam Pengembangan Komoditi Unggulan Kabupaten Agam. ECONOMICA: Journal of Economic and Economic Education, 3(1), 27-41. https://doi.org/10.22202/economica.2014.v3.i1.234 